Економічні науки: збірник наукових праць Луиького національного технічного університету. Серія "Регіональна економіка". Випуск 17 (67). Редкол.: відп. ред. к.е.н., професор І.В. Кривов’язюк. Луцьк: ІВВ Луцького НТУ, 2020. 348 с.

УДК 332.122

Дащук Ю.Є., к.е.н., ст. викладач

Луцький національний технічний університет

\title{
ЕНОГАСТРОНОМІЧНИЙ МАРШРУТ ЯК ІНСТРУМЕНТ РОЗВИТКУ ГОТЕЛЬНО-РЕСТОРАННОГО БІЗНЕСУ СІЛЬСЬКИХ ТЕРИТОРІЙ
}

У статті розглянуто сутність поняття «еногастрономічний туризм», розкрито підходи до формування та особливості розвитку еногастрономічних туристичних маршрутів в Україні. Обгрунтовано їх важливість для розвитку сфери послуг у сільській місцевості.

Ключові слова: сфера послуг, готельно-ресторанне господарство, сфера гостинності, туристичне обслуговування, еногастрономічний маршрут, гастрономічний туризм.

\section{Dashchuk Y.}

\section{ENOGASTRONOMIC TOURISM BASED AS A TOOL FOR DEVELOPMENT OF HOTEL AND RESTAURANT BUSINESS OF RURAL AREAS}

The article considers the essence of the concept of "enogastronomic tourism". It was found that this type of service is gaining popularity among tourists both in the world and in Ukraine. Among the biggest problems for the development of this area of hospitality are the chaotic cooperation of tourism entities, the low level of quality of service, the lack of a clear legal framework. The paper proves that the enogastronomic route is an important multiplier for the effective development of the hotel and restaurant business in rural areas. In particular, in terms of supporting producers who have geographical indications and traditional products; preservation and strengthening of biodiversity and cultural heritage of local communities; integration of agricultural production and tourism; diversification of production activities in rural areas and attracting additional financial income from tourists and investors. As an example of effective interaction and effectiveness of cooperation of a wide range of stakeholders in the hospitality industry in Ukraine, examples of enogastronomic routes are given: "The road of wine and taste of Ukrainian Bessarabia" and "The road of wine and taste of Transcarpathia". Such practices have proven their effectiveness in terms of quality development of local industries, with an emphasis on the uniqueness of manufactured products and the development of the logistics aspect of routes. Thus, the formation of enogastronomic tourist routes allows you to combine national history and culture, traditions of local food and beverages and present them as a comprehensive tourist product to potential consumers. This approach will have a positive impact on increasing 
Економічні науки: збірник наукових праць Луиького національного технічного університету. Серія "Регіональна економіка". Випуск 17 (67). Редкол.: відп. ред. к.е.н., професор І.В. Кривов’язюк. Луцьк: ІВВ Луцького НТУ, 2020. 348 с.

the number of tourists, the profitability of the tourism business, the level of employment, will help attract investment in the development of domestic producers, economic development and its recognition at the global level.

Key words: sphere of services, hotel and restaurant economy, sphere of hospitality, tourist service, enogastronomic route, gastronomic tourism.

Дащук Ю.Е.

\section{ЭНОГАСТРОНОМИЧЕСКИЙ МАРШРУТ КАК ИНСТРУМЕНТ РАЗВИТИЯ ГОСТИНИЧНО- РЕСТОРАННОГО БИЗНЕСА СЕЛЬСКИХ ТЕРРИТОРИЙ}

В статье рассмотрена сущность понятия «эногастрономический» туризм», раскрыто подходы к формированию и особенности развития эногастрономических туристических маршрутов в Украине. Обоснованно их важность для развития сферы услуг в сельской местности.

Ключевые слова: сфера услуг, гостинично-ресторанное хозяйство, сфера гостеприимства, туристическое обслуживание, эногастрономический маршрут, гастрономический туризм.

\section{Постановка проблеми у загальному вигляді та іiі} зв'язок 3 важливими науковими та практичними завданнями.

Сучасні тенденції розвитку сфери гостинності засвідчують зростання популярності еногастономічного туризму у світі. Цьому сприяє ряд факторів, зокрема, пошук нових відчуттів, перехід від масових до індивідуальних програмам відпочинку, прагнення сучасного туриста глибше знати, що він споживає. Більшість регіонів України мають високий гастрономічний виробничий та туристсько-рекреаційний потенціал для розвитку успішного еногастрономічного туризму. Проблема такого розвитку полягає в хаотичній співпраці суб'єктів туристичної діяльності, низькому рівні якості послуг сфери гостинності. Так, існує нагальна потреба створення моделі формування еногастрономічних туристичних маршрутів, яка забезпечить подальшу ефективну інтеграційну взаємодію представників гастрономічної та туристичної галузей на усіх ієрархічних рівнях для створення якісних еногастрономічних туристичних пропозицій та формування еногастрономічних туристичних дестинацій в регіонах країни. 
Економічні науки: збірник наукових праць Луиького національного технічного університету. Серія "Регіональна економіка". Випуск 17 (67). Редкол.: відп. ред. к.е.н., професор І.В. Кривов'язюк. Луиьк: ІВВ Луцького НТУ, 2020. 348 с.

\section{Аналіз останніх досліджень, у яких започатковано вирішення проблеми.}

Аналіз наукової та фахової літератури свідчить про актуальність та своєчасність дослідження проблеми розвитку еногастрономічного туризму. Вагомий внесок у розвиток теоретичних та методичних положень цієї теми зробили Басюк Д.І. [1], Любіцева О.О. [2], Шандор Ф.Ф. [3] та ін. В працях вчених розглядаються історико-культурний контекст розвитку цього виду туризму, особливості створення регіональних туристичних продуктів на основі національних виноробних традицій. Серед іноземних авторів цією проблемою займалися Гетс Д. [4], Гендерсон Дж. [5] та ін. Але запропоновані підходи зазначених авторів не повністю розкривають специфіку розвитку еногастрономічних маршрутів як інструменту розвитку готельноресторанного бізнесу сільських територій.

Цілі статті. Метою дослідження є обгрунтування важливості розвитку еногастрономісних маршрутів для активізації сфери гостинності в сільських територіях.

\section{Виклад основного матеріалу дослідження 3 повним обгрунтуванням отриманих наукових результатів}

Слід відзначити, що єдиного підходу до трактування поняття «еногастрономічний» туризм в науковій літературі, на сьогодні, не сформовано. Зазвичай, вживаються терміни «винний туризм», «виноробний туризм», «дегустаційний туризм», «винногастрономічний туризм» та «енотуризм». Часто зустрічаються терміни «пивні тури», «віскі-тури». Окремі фахівці розглядають досліджуваний вид туризму як різновид гастрономічного туризму, хоббі-туризму, подекуди спеціалізованого туризму. Інколи можна зустріти визначення «алкотуризм» i «П'яний туризм» - подорож в будь-яку географічну місцевість з метою розпиття спиртних напоїв.

В працях вчених зустрічається поняття енотуризму. Так, енологія - наука про вино, виноробство - контрольований процес перетворення виноградного соку у вино шляхом бродіння 3 технологією подальшого догляду за ним та його правильного зберігання, визначає доцільність терміну енотуризм - туризм 3 
Економічні науки: збірник наукових праць Луиького національного технічного університету. Серія "Регіональна економіка". Випуск 17 (67). Редкол.: відп. ред. к.е.н., професор І.В. Кривов'язюк. Луиьк: ІВВ Луцького НТУ, 2020. 348 с.

метою ознайомлення з технологією виробництва та дегустацією вин, який $є$ синонімічним до винного туризму.

Дедалі частіше в наукових працях зустрічається дефініція «геотуризм» - подорожі присвячені дослідженню унікальності культури та історії окремих регіонів i місць, пошуку диверсифікованості у глобалізованому світу. Сутність геотуризму полягає у можливості відчувати переваги подорожі територією, наділеною характерними особливостями, ознайомлюватися 3 ними, не заподіюючи шкоди i сприяючи збереженню та відновленню місцевої унікальності.

На думку Басюк Д.І. [4] еногастрономічний туризм - це туризм, який передбачає вивчення традиційних для конкретної місцевості продуктів, алкогольних та безалкогольних напоїв та культури їх поєднання та споживання. Дефініція «еногастрономія» походить від злиття двох інших латинських слів: «ено»- вино і «гастрономія», тобто «правила прийому їжі». У масовому вжитку еногастрономія розуміється як система правил $з$ правильного підбору вина до тієї чи іншої страви, щоб отримати в результаті, приємне смакове поєднання. Тобто еногастрономія, перш за все, дає рекомендації, відповідно до яких, до кожної конкретної страви підбирається відповідний сорт вина, таким чином, щоб благородний напій максимально гармонійно поєднувався зі смаком їжі і підкреслював якість продуктів. Одним із головних правил енограстрономії $є$ теза, що до регіональної кухні найкраще підійде вино, зроблене 3 винограду, вирощеного в даному регіоні. Це правило можна назвати «географічним» або «регіональним» принципом еногастрономії, тобто під вино даної країни найкраще підійде блюдо цієї країни і навпаки. Зазначимо, що у розвинутих країнах Європи еногастрономія стає науковою дисципліною, яка досліджує якість страв i напоїв, розробляє їх сенсорні характеристики, вивчає особливості типових місцевих продуктів i т.п. Для цього найчастіше використовують еногастрономічні маршрути - це так звані «Дороги Вина», «Дороги Смаку», «Дороги Вина та Смаку», які включають кулінарну спадщину, яка $є$ унікальною у кожному регіоні. Турист має можливість 
Економічні науки: збірник наукових праць Луиького національного технічного університету. Серія "Регіональна економіка". Випуск 17 (67). Редкол.: відп. ред. к.е.н., професор І.В. Кривов'язюк. Луиьк: ІВВ Луцького НТУ, 2020. 348 с.

відвідати різні виноробні, продегустувати місцеві вина, побувати на виробництві місцевих продуктів харчування та поїсти у ресторанах з традиційною кухнею.

Загалом, еногастрономічні туристичні маршрути - це інноваційний для України туристичний продукт, який сприяє комплексному розвитку територій через:

- підтримку виробників продукції 3 географічними зазначеннями та традиційних продуктів;

- збереження та зміцнення біорозмаїття i культурної спадщини місцевих спільнот;

-інтегрований розвиток агровиробництва та туризму;

- диверсифікацію виробничої діяльності у сільській місцевості та залучення додаткових фінансових надходжень від туристів та інвесторів.

Поряд 3 цим, варто акцентувати увагу, що зазначені маршрути сприяють популяризації саме автентичної української кухні та традиційних вин, страв регіонів України. Це сприяє формуванню позитивного іміджу регіонів та їх гастрономічних брендів. На нашу думку, успіх еногастрономічних туристичних маршрутів залежить від кількох складових: локальних туристичних атракцій, культурних пропозицій i розвитку інфраструктури - доступу до доріг, аеропортів тощо.

В Україні, на сьогодні, функціонує два еногастрономічні туристичних маршрути: «Дорога вина та смаку української Бессарабії» та «Дорга вина та смаку Закарпаття» (рис.1).
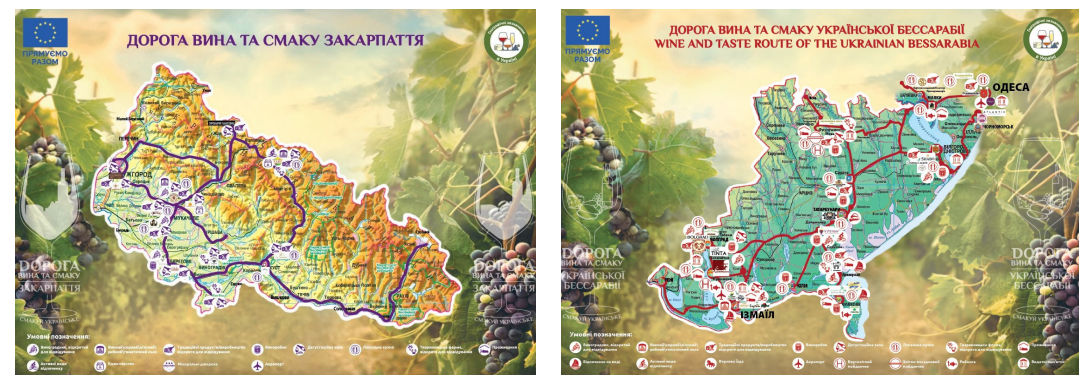

Рис. 1 Карти еногастрономічних маршрутутів в Украӥні 
Економічні науки: збірник наукових праць Луиького національного технічного університету. Серія "Регіональна економіка". Випуск 17 (67). Редкол.: відп. ред. к.е.н., професор І.В. Кривов'язюк. Луиьк: ІВВ Луцького НТУ, 2020. 348 с.

В рамках представлених маршрутів туристи мають можливість провести дегустації продуктів місцевого виробництва, провести майстер-класи. Варто зазначити, що у перелік локацій, рекомендованих для відвідування, входять об'єкти, які відповідають основним вимогам: легальність ведення бізнесу і високий рівень сервісу. Такий підхід стимулює малий бізнес сільських територій до ефективної діяльності й дає можливість включення туристичних дестинацій сільських підприємців на мапу «Дороги вина та смаку». Такий підхід дозволяє: для регіональних виробників якісної продукції отримати законодавчо захищену назву продукту - відповідне географічне зазначення; для споживачів продукт з географічним зазначенням - це гарантія того, що він отримує високоякісний автентичний продукт.

Представлені туристичні еногастрономічні маршрути «Дороги вина та смаку» дозволяють впровадити в Україні інноваційний досвід Європейських регіональних студій i сприяють розвитку сільських територій півдня та південного заходу України. Також подібні практики дають поштовх до якісного розвитку локальних виробництв, 3 акцентом на унікальність виготовлених продуктів та розвиток логістичного аспекту маршрутів, який враховує порядок локацій, час i комфорт переїздів, ночівель тощо.

Висновки. Таким чином, формування еногастрономічних туристичних маршрутів дозволяє поєднати національні історію та культуру, традиції виробництва місцевих страв та напоїв та представити їх як комплексний туристичний продукт потенційним споживачам. 3 іншого боку взаємодія широкого кола стейкхолдерів сфери послуг дозволяє не лише розкрити гастрономічний ресурсний потенціалу на локальному рівні, але й сформувати ефективну модель розвитку готельноресторанного бізнесу на засадах сталості. Такий підхід позитивно впливає на збільшення кількості туристів, прибутковість туристичного бізнесу, рівень зайнятості населення, сприяє залученню інвестицій у розвиток вітчизняних 
Економічні науки: збірник наукових праџь Луцького національного технічного університету. Серія "Регіональна економіка". Випуск 17 (67). Редкол.: відп. ред. к.е.н., професор І.В. Кривов’язюк. Луцьк: ІВВ Луцького НТУ, 2020. 348 с.

товаровиробників, розвитку економіки країни та її визнанню на світовому рівні.

\section{Список бібліографічного опису}

1. Басюк Д. І. Інноваційний розвиток гастрономічного туризму в Україні. Наукові праці Національного університету харчових технологій. 2012. № 45. C. $138-143$.

2. Любіцева О. О. Перспективи розвитку винного туризму в Україні: світовий контекст. Географія та туризм. 2013. Вип. 24. С. 93-99.

3. Шандор Ф.Ф. Кляп М.П. Сучасні різновиди туризму: підручник. Київ: Знання, 2013. $334 \mathrm{c}$.

4. Getz, D. (2000). Explore Wine Tourism: Management, Development \& Destinations. New York: Cognizant Communication Corporation.

5. Henderson, J. (2009). Food Tourism Reviewed, British Food Journal, 111(4), 317-326.

\section{References}

1. Basiuk D.I. Innovative development of gastronomic tourism in Ukraine / D.I. Basiuk // Scientific works of the National University of Food Technologies. K., 2012.\# 45. P. 138-143.

2. Lyubitseva, O.O. (2013). Prospects for the development of wine tourism in Ukraine: world context. Geography and Tourism, 24, 93-99 [in Ukrainian].

3. Shandor, F.F. \& Klyap, M.P. (2013). Modern types of tourism. Kiev: Knowledge [in Ukrainian].

4. Getz, D. (2000). Explore Wine Tourism: Management, Development \& Destinations. New York: Cognizant Communication Corporation.

Henderson, J. (2009). Food Tourism Reviewed. British Food Journal, 111(4), $317-326$. 